\title{
Studies on palliative care, mourning and death conducted as part of a graduate program in psychology in the Amazon Region
}

Keywords: study, palliative care, mourning, death, Amazon

Abbreviations: UFPa, federal university of pará; LAELS, laboratório de estudos do luto e saúde; LEM, laboratório de estudos sobre a morte; SCPO, serviço de cuidados paliativos oncológicos; COPD, chronic obstructive pulmonary disease; CCPO, clínica de cuidados paliativos oncológicos

\section{Introduction}

Research in the field of psychological prevention and intervention on human beings throughout the life cycle is necessary and urgent. When considering the experiences of extreme circumstances, such as the occurrence of a disease that cannot be cured or when death is imminent, it becomes essential in supporting clinical practice, subsidizing health actions, while at the same time ratifying the important interaction between research and intervention.

In this study, our objective is to evaluate the progress of studies on palliative care, death and mourning, carried out by the students of a Graduate Program in Psychology connected with the LAELS from the UFPa. This university is located in the city of Belém, in the state of Pará, in northern Brazil, which is part of the Brazilian Amazon region.

LAELS is an extension project undertaken at the Federal University of Pará, connected with the Institute of Philosophy and Human Sciences, the Faculty of Psychology and the Graduate Program in Psychology. Currently, it maintains partnerships with three public hospitals in the region: the João de Barros Barreto University Hospital, the Gaspar Viana Clinical Hospital Foundation and the Octávio Lobo Children's Hospital. This project dates to 2008, when other laboratories were already being implemented in the southeast region of Brazil. Thus, this laboratory maintains a partnership with the Laboratory of Studies on Death of the Institute of Psychology of the University of São Paulo, a laboratory implemented in the southeastern region of the country.

LAELS is an interdisciplinary area for dialogues about knowledge and practices related to the conditions of mourning, health crisis and promotion, including issues related to palliative care. Through this project, actions in thanatology education are undertaken, with emphasis on the implementation of work groups focused on the task of dialogue on the subjects of death and dying and others requested by participants, including those related to palliative care in order to foster the development of research in the area. It is a project that links research and extension as interdependent actions, defending the need for an education for death, ${ }^{1}$ understood as: A study on the possibility of personal development in a more integral way, in the sense understood by Jung (1960) as individuation, as inner development that is proposed during existence, which also presupposes preparation for death. It is this proposal of education, which I now present, involving communication, relationships, losses, and extreme circumstances. It includes the stages of development, the loss of loved ones, illnesses, accidents, even confrontation with one's own death.
Volume 2 Issue 4 - 2018

\author{
Souza AM,' Kovacs MJ, ${ }^{2}$ Corrêa VAC,, ${ }^{3}$ Costa \\ NGB' \\ 'Institute of Philosophy and Social Sciences of the Federal \\ University of Pará, Brasil \\ ${ }^{2}$ Institute of Psychology, University of São Paulo, Brasil \\ ${ }^{3}$ Institute of Health Sciences of the Federal University of Pará, \\ Brasil
}

Correspondence: Souza AM, Institute of Philosophy and Social Sciences of the Federal University of Pará, LAELS Coordinator, Psg Severa Ronama, 14, Bairro Sacramenta. Belém Pará, Cep 66 I20370, Brasil, Email airlemiranda@gmail.com

Received: August 17, 2017 | Published: July 13, 2018

Two groups of health professionals and the like, as well as undergraduate and graduate students from public hospitals of the region participated in the study. Among the various participants the Residents from the multi-professional Health Residency Program, from the following areas of concentration stand out: Oncology and Geriatric Care; (Psychologists, Nurses, Occupational Therapists, Social Services, Pharmacists, Biomedical professionals, and Radiology Technicians); from the Residency Program in Palliative Care; from the multi-professional Residency Program in Cardiovascular Health Care, in addition to undergraduate students in Psychology, Occupational Therapy, Nursing, and Social Work; and health professionals who work in pediatric oncology, among others.

These practices have contributed to educational actions in relation to life and death, highlighting the importance of humanized care, multi and interdisciplinary work for symptom relief and control, quality of life from diagnosis to the finitude to favor a holistic view of care.

In order to achieve the proposed aims of this study, a survey was conducted of the research carried out in the period from 20102016, using as inclusion criteria: a link to the Graduate Program in Psychology of the UFPa and to the LAELS; the academic master's degree; and, a relation to one of the three following topics: palliative care, mourning or death. Projects that did not meet these criteria were not included. The data were inserted in an Excel worksheet, using the following categories for analysis: year, author, line of research, master's or doctorate level, methodology, objectives and their results.

From the selected time period, eleven (11) dissertations were identified, related to the following topics:

i. Palliative care, investigating patients', relatives' or health professionals' experiences in these programs.

ii. Mourning and its unfolding. Among these studies, the following stand out. 


\section{Facial deformation as a result of cancer and the necessary support: spaces of care for integration ${ }^{2}$}

Dissertation in the Psychological Prevention and Treatment line of research addressing the issue of holding (support) in the care of patients with face and neck cancer. It is a theoretical study, based on Winnicott. The results emphasize the emergence of a state of confusion, renewing primitive anxieties of disintegration and devastation, requiring a reorganization of defenses. Holding is highlighted as a favorable element in the preparation of losses due to illness and its progression. It is important to highlight the need for holding made available by family members, health teams, and by the health institution itself.

\section{Mourning for the loss of health: experiences of mothers of children with cystic fibrosis ${ }^{3}$}

Dissertation in the Psychological Prevention and Treatment line of research, which discusses the suffering of patients with cystic fibrosis - a chronic disease of genetic etiology without a cure that is potentially lethal and has a reserved prognosis - and the mourning experience of the mothers, whose children were patients of the study. A semi-structured interview was carried out from a qualitative clinical approach with the use of two layouts for subsequent analysis of the content presented by the mothers. The results indicate that they experience mourning for the loss of the child's health, at the same time they reveal meanings attributed to death and dying, while aware of the threat of death. Imminent death triggers reorganization and personal and familiar internal and external changes that favor the redefining of their lives based on the confrontation with the disease.

\section{Groups focused on the task of discussing death and dying: their meanings ${ }^{4}$}

A dissertation in the Psychological Prevention and Treatment line of research to investigate the groups focused on the task of discussing death and dying at the hospital. The feelings and meanings attributed by its members are evaluated. Ten professionals who attended the groups more than five times were interviewed from a clinicalqualitative approach. Content analysis was carried out, considering the following categories:

i. Who are the people who come to talk about death and dying.

ii. The group as a space for learning and personal development.

iii. Education groups for death. The results indicate that professionals seek and join the group by spontaneous demand, and that in each encounter specific demands emerge. From the dialectic of the arrival and departure of members, since they are open and flexible groups, the sense of transience, of the impermanence of life is revealed. Among the main meanings identified from the participation of these groups, the search for personal and professional development stands out; from the groups identified as therapeutic spaces of sharing, reflection and learning stood out. Dialogue on death and dying contributes to formation and development, constituting a strategy of education for life and death and a cultural action for freedom.

\section{Scenes about death, revealed by the child with heart disease, before open-heart surgery ${ }^{5}$}

Dissertation in the Psychological Prevention and Treatment line of research with the objective of understanding the experience of children in the face of cardiac surgery and unveiling meanings attributed to death. It is a study with a qualitative approach of the case study type. Five children with congenital heart defects, aged between six and twelve, participated. An interview with the parents and three thematic meetings with the children were carried out using: (1) drawings (2) collages, both of which were followed by verbalization about the production and (3) completing of the story. The results indicate that cardiac surgery is perceived as a personal death threat and "cutting the heart" represents an attack that can result in death. The personification of death was identified from everyday elements from river life, represented by the jaguar, river water bugs, a boat about to be destroyed by a wave and instruments for hunting animals, all common in the Amazonian culture. The taboo of the topic of death and the suffering of family members and health staff are perceived by the children, who reaffirm the need to talk about the threat of death and the fears evoked in the pre-cardiac surgery period.

\section{Children should not die: meanings attributed by health professionals to alleviate children in the process of imminent death ${ }^{6}$}

Dissertation in the Psychological Prevention and Treatment line of research seeking to understand the meanings attributed by professionals, who work in the pediatric ward, to caring for children with illnesses that cannot be cured, are hospitalized and in the process of dying. Based on the qualitative approach, twelve professionals participated in interviews: (3 Physicians, 1 Psychologist, 1 Occupational Therapist, 2 Nurses, 1 Physiotherapist, 1 Social Worker and 3 Nursing Technicians). Three central themes emerged: Denial and Forbidden Death Attachment andthe Experience of Grief; and, Training for Palliative Care. For the participating professionals, providing palliative care is an arduous task requiring extreme care for the child without curative therapeutic possibilities. However, in the impossibility of avoiding death, they can experience intense suffering, favoring stubborn actions to stay alive with denial and forbidden death. The absence of coursework addressing these subjects in graduate studies was identified. The data point to the strangeness of the child's death and the experience of unauthorized mourning, corroborating the importance of education for life and death.

The process of mourning by the elderly for the death of the spouse: memories, emotions and lives that follow ${ }^{7}$

Dissertation in the Psychological Prevention and Treatment line of research with the purpose of understanding the experience of the elderly after the death of the spouse. The methodology of a qualitative approach, with case studies included the participation of four elderly people, whose age was 60 years or greater when they experienced the death of the spouse; the a minimum time of widowhood of 12 months was established for the two men and two women who were being cared for in a Geriatric Program in a Municipal Health Unit. An interview and an expressive workshop activity were carried out. The results 
highlight the uniqueness of the cases as well as factors associated with the experience of mourning: time and quality of conjugal coexistence; the deceased spouse's illness and its repercussions; religious beliefs; Conceptions about death and dying and the very condition of being old in the face of loss, as well as differences between genders, were important variables in the experience of mourning.

\section{Hospitalized and palliative care for geriatric oncology: the possibility of doing, being and becoming in finitude ${ }^{8}$}

A dissertation in the Psychological Prevention and Treatment line of research, aiming to understand the meanings of death and dying and their relationship with the occupations of the hospitalized elderly receiving oncological palliative care. This is a qualitative study, carried out through a case study. Two elderly women were admitted to the medical clinic of a university hospital. The tools used were an open interview, a bonding activity, a free activity and a questionnaire. The elderly women revealed different ways of understanding the process of dying, with different meanings and attitudes. It was perceived that activities during hospitalization can be carried out in a manner conducive to life, as well as a possibility of denying impending death and as a farewell to its existence - a continuous elaboration of actual and near death. It was perceived that occupations as an expression of the totality of human existence are genuine, singular, subjective and constructed forms in the process of experiencing finitude.

\section{Outpatient denial of oncology palliative care in the dying process $2014^{9}$}

Dissertation in the Psychological Prevention and Treatment line of research, aiming to understand how patients hospitalized in oncology palliative care experience the process of finitude. It was attempted to understand death as the process of denouement of living, revealing the meanings attributed to life and death from the diagnosis of a serious, advanced illness without possibilities of treatment or hope for healing. The methodological strategy was a qualitative approach of the case study in which six patients, three men and three women, one young adult and five elderly, who were hospitalized with an advanced cancer diagnosis, and who had been informed of their referral for palliative care, and had begun care with the OPCS [Oncological Palliative Care Service (Serviço de Cuidados Paliativos Oncológicos)] team. The psychological interview was the method used. The meetings were held three times a week on average, and the data were analyzed through thematic content analysis. The central themes identified were: attitudes towards death; planning for the future in the face of imminent death; the return home; the need to be in a family environment, close to loved ones and the difficult task of breaking bonds, how to separate from loved ones. These factors interfere in the process of dying, emphasizing listening and quality care as fundamental to a "good death". The process of dying is unveiled as the outcome of everything that connects life to the concept of death beyond the decline of vital functions, including the desires, needs and experiences of those who are dying, as well as the awareness and acceptance that death is a certain and near fate.

Boating disasters in amazonia published in newspapers (2002-20|3): a study in the light of the psychology of emergencies, disasters and grief ${ }^{10}$

A dissertation in the Psychological Prevention and Treatment line of research in which the occurrence of ship disasters in the region were identified, discussing these events with a focus on the psychology of emergencies and disasters and studies on mourning. The method used was documentary analysis, complemented with content analysis. Three regional printed journals published between 2002 and 2013 were analyzed. The number of deaths, only for cases of shipwrecks, analyzed in the study was 222 and the number of survivors 1,689 , including the deaths of many children. In addition to discussing the event and losses as traumatic, attention was called to the adoption of measures in the form of: public policies to assist the populations living in the many locations in the Amazon; improvement or deployment of health services (which is why many people need to travel long distances from their homes); the development of educational strategies on boating safety; improvement of the system of supervision and implementation of quality public transport.

\section{On loss, mourning and "suffocation": revealing stories of patients with chronic obstructive pulmonary disease ${ }^{\prime \prime}$}

Dissertation in the phenomenology: Theory and Clinic line of research aimed at understanding the meanings attributed to living with COPD - Chronic Obstructive Pulmonary Disease, a continual threat to the lives of individuals with the illness because it is a chronic disease, whose progressive path includes limitations and incapacities to perform activities of daily living, which is potentially lethal. With a qualitative approach, using the Oral History Thematic technique, it was possible for the collaborators to tell their life stories influenced by the experience of being a COPD patient. Carried out in the outpatient clinic for patients with COPD at a university hospital, six patients participated, three men and three women. To analyze the data, content analysis was used, and three themes were identified: limitations and losses from diagnosis with COPD; mourning for what dies every day; the suffocation present in dyspnea: beyond respiratory insufficiency. The results point to the experience of many losses in various aspects of life: economic, social, familiar, and sexual, among others. These losses are felt as small deaths of oneself, which causes grief and require the experience of mourning. The need to promote care spaces for this population, such as in waiting room environments, which may provide therapeutic moments for the drafting of losses, as well as insertion by the health teams in the patients' family and social networks is highlighted.

\section{Living and dying for patients und er oncological palliative care: revealing the meanings of life ${ }^{12}$}

Dissertation in the Phenomenology: Theory and Clinic line of research, with the aim of unveiling the meanings of the lives of patients under oncological palliative care. Contact with the vulnerability of existence is a trigger for questions about the purpose and meaning of life was highlighted, allowing finitude and death to become meaningful, as it shows the uniqueness of human existence. The study was conducted at the CCPO, the first structured palliative care service in the northern region of Brazil, in operation since 2001 at Ophir Loyola Hospital, a reference unit for the treatment of high complexity cancers in Belem, Pará, based on the phenomenological investigation method. Four patients with metastatic cancer under palliative care were invited to respond to the prompt, "What gives meaning to your life?" The analysis of the accounts reveals that in the face of finitude, of the impossibility of projecting, dreaming, or wishing, that the guarantee of existence is found in what is lived; that is, in the past. It is precisely the past, the way the person told his story, that the lived gives meaning to life. It emphasizes the uniqueness of living and dying and the way in which the meanings of life are 
revealed. The stories of the lived need to be told and need interested and attentive listeners. Caring for people who experience finitude requires a loving and empathetic capacity that allows for the division/ sharing of living and dying.

In the time period, eleven studies were conducted, where 2014 was the most represented year, with four studies presented. During the study, all the authors were part of the LAELS, participating in the groups carried out in this laboratory. Even after completing their studies, they actively participated in the activities, and currently are coordinating study groups addressing the themes of death and dying in the institutions where they work. All the studies are Master's level and are linked to two lines of research of said program.

\section{The Phenomenology}

Theory and Clinic line, was recently implemented in 2015/2016, so it still has a smaller number of studies. As for the method, all the projects used a qualitative approach, which contributes to highlighting the singularity of the cases and the data collection, allowing a deep understanding of the studied subjects, particularly death and mourning. Most of the studies are carried out in health institutions - public university hospitals in the region - and their results call into question relevant issues, which should be considered in the planning of actions for users living in situations of loss, illness, death and mourning.

It should be emphasized that in some of these studies, although palliative care is not explicitly stated as the object of the study, the projects contribute to the production of knowledge in the area of palliative care while including people with chronic diseases, their relatives or health professionals in their studies. This graduate program makes an important contribution to the production of knowledge in this area, receiving researchers interested in addressing the topics in question and the public university hospitals in the region for receiving these researchers and their research proposals each year. On the other hand, it should be highlighted that these researchers chose crucial issues of human existence for their topic of research: illness, suffering and death.

Finally, from these studies we can learn about the experiences of people experiencing extreme circumstances and about the human capacity to face adversities by giving them meaning. It is certain that we must continue, stimulating our studies in this field, in hopes that we can advance humanized, holistic care in favor of human dignity in Brazil.

\section{Acknowledgements}

None.

\section{Conflict of interest}

The author declares no conflict of interest.

\section{References}

1. Kovács Maria Julia. Educação para a morte. Psicologia: Ciência e Profissão. 2005;25(3):484-497.

2. Barros MLP. O rosto deformado em decorrência do câncer e a sustentação necessária: espaços de cuidados à integração. Dissertação Mestrado, Universidade Federal do Pará, Belém, Brasil, Programa de Pós Graduação em Psicologia; 2010:91 p.

3. Almeida NL. O Luto Pela Perda da Saúde: vivências de ser mãe de uma criança com fibrose cística. Dissertação Mestrado, Universidade Federal do Pará, Instituto de Filosofia e Ciências Humanas, Belém, Brasil, Programa de Pós Graduação em Psicologia; 2012.

4. Heringer CF. Grupos centrados na tarefa de dialogar sobre a morte e o morrer: sobre seus significados. Dissertação Mestrado, Universidade Federal do Pará, Belém, Brasil, Programa de Pós Graduação em Psicologia; 2012:92 p.

5. Aita KMSC. Cenas sobre a morte, reveladas pela criança cardiopata, por abrir o coração. Dissertação Mestrado, Programa de Pós Graduação em Psicologia, Universidade Federal do Pará, Belém, Brasil, Programa de Pós Graduação em Psicologia; 2012:91 p.

6. Pampolha SSAP. Criança não deveria morrer: significados atribuídos por profissionais de saúde ao paliar crianças em processo de morte iminente. Dissertação Mestrado, Universidade Federal do Pará, Belém, Brasil, Programa de Pós Graduação em Psicologia; 2013.

7. Coutinho DF. O Processo de Luto do Idoso por Morte do Cônjuge: memórias, emoções e vidas que seguem. Dissertação Mestrado, Universidade Federal do Pará, Belém, Brasil, Programa de Pós Graduação em Psicologia; 2014:93 p.

8. Souza GGA. Idosos Hospitalizados e em Cuidados Paliativos Oncológicos: a possibilidade de fazer, ser e tornar-se na finitude. Dissertação Mestrado, Universidade Federal do Pará, Belém, Brasil, Programa de Pós Graduação em Psicologia; 2014:108 p.

9. Mota CP. Desenlace de pacientes hospitalizados em cuidados paliativos oncológicos no processo de morrer. Dissertação Mestrado, Universidade Federal do Pará, Belém, Brasil, Programa de Pós Graduação em Psicologia. 2014:99 p.

10. Souza CP. Desastres de barcos na Amazônia divulgados em jornais (2002-2013): um estudo a luz da Psicologia das Emergências e Desastres e do Luto. Dissertação Mestrado, Universidade Federal do Pará, Belém, Brasil, Programa de Pós Graduação em Psicologia; 2014:128 p.

11. Castello LN. Sobre perdas, lutos e "sufoco": desvelando histórias de pacientes com doença pulmonar obstrutiva crônica. Dissertação Mestrado, Universidade Federal do Pará, Belém, Brasil, Programa de Pós Graduação em Psicologia; 2016:119 p.

12. Gama ESC. O viver e o morrer para pacientes sob cuidados paliativos oncológicos: desvelando os sentidos da vida. Dissertação Mestrado, Universidade Federal do Pará, Belém, Brasil, Programa de Pós Graduação em Psicologia; 2016:175 p. 